\title{
Conservation Crisis in Marat Longri Wildlife Sanctuary, Assam, India
}

\section{Urmika Phangchopi*, Robindra Teron, Ajit K. Tamuli}

Department of Life Science \& Bioinformatics, Assam UniversityDiphu Campus, Diphu, Karbi Anglong, Assam-782462, India

\section{Study Area: Marat Longri Wildlife Sanctuary, India \\ Coordinates: $25^{\circ} 47^{\prime}-25^{\circ} 59^{\prime} \mathrm{N} ; 93^{\circ} 08^{\prime}-93^{\circ} 21^{\prime} \mathrm{E}$}

Key words: Jhum, Domestication, Agroforestry

\section{Abstract}

People-forest interactions in protected area have been debated around the world. The present study evaluates land-use pattern, diversity and utilization of forest resources in Marat Longri Wildlife Sanctuary (WLS) using semi-structured interview, remote sensing, and Global Information System (GIS) techniques. Such study can have many implications on people-forest interactions in the sanctuary and promote symbiotic approach in dealing with biodiversity conservation in protected area. Marat Longri WLS is indispensable to forest dwellers for subsistence and livelihoods. The result of pair-wise ranking revealed jhum (3160) is the major threat to forest cover followed by illegal felling (2850), agricultural expansion (2346), encroachment (2211) and collection pressure (2080). To reduce dependence on Marat Longri WLS, domestication of wild plants and other agroforestry systems can augment food production and realize other needs of forest dwellers.

Agol, . Despite its relevance, quantitative national-level information on drivers and activities causing deforestation and forest degradation are widely unknown in many developing and under-developed countries. Most scientific research are based on local-scale studies or regional to global assessments (Geist \& Lambin, 2001; De Fries et al., 2010, Boucher et al., 2011), highlighting the importance of differences between proximate or direct drivers and indirect causes. In recent times, Remote Sensing and Geographical Information System (GIS) techniques are becoming an assessment and management tool for observing the changes in the forest cover, classif ication of forest and the ecosystems by using Forest Transition Model (Assessment Method). It also helps to prioritise the efforts of conservation and mitigation of the issues by integrating the spatial and non-spatial information (Salem, 2003; Ambastha \& Jha, 2010; Pattanaik et al., 2010; Roy et al., 2013). Marat Longri Wildlife Sanctuary (WLS) in Karbi Anglong district, Assam provides an apt case for investigating people-forest interactions. About 98 villages belonging to seven ethnic groups are located within and on the fringe of the sanctuary. The forest resources are the main source of subsistence and livelihoods to the inhabitants as agricultural land is limited and food production is not adequate for the whole year. This demands higher dependence on forest resources for food, livelihood, 
construction and other requirements (Kar \& Borthakur, 2007; Phangchopi et al., 2014, 2015). Land-use pattern particularly slashes and burn a griculture ( J h u m), encroachment and conversion of forest into agricultural land are major factors contributing to a loss of biodiversity, overexploitation and habitat modification or fragmentation in this PA. Forest status map of 2012 for the sanctuary showed large-scale fragmentation and encroachment (Fig.-1). In the above context, there is a pressing need for effective conservation strategy in Marat Longri WLS without disrupting the socio-cultural practice of the forest inhabitants. Also, it is important to understand how the spatial distribution of disturbance regimes reached its current state for initiating effective measures of conservation. The state of Assam located in the northeast of India has an area of $78,438 \mathrm{~km} 2$ and based on the satellite data analysis by Assam Remote Sensing Application Centre (ARSAC) the state had an area of $19,766.38 \mathrm{~km} 2$ (25.2\%) under forest-cover during 1980-82 and subsequently declined to $17,263.87 \mathrm{~km}^{2}(21.98 \%)$ for which the status of PAs is not bright. The Reserved Forests occupy around 15,030.18 km² accounting for 19.14 percent of the State's total geographical area (Talukdar, 2014). Though the national goal is to have a minimum of onethird of the total geographical area of the country under forest or tree cover but the shrinkage of Reserve forest or PAs (which is considered to be natural forest) is a major concern in the present day. The scenario within the notified PAs reveals a gloomy state in terms of degradation during last two decades under various biotic pressures. The present study evaluated the land-use pattern, diversity, and utilization of forest resources in Marat Longri WLS. The study further assessed drivers of forest/habitat degradation and suggests for an exigent conservation of the sanctuary.

\section{Materialsand methods:}

Study area: Marat Longri Wild Life Sanctuary was established on 17th April 2003 with a geographical area of $451.00 \mathrm{~km} 2$. The sanctuary comprises four Reserved Forests (RF); namely - Mijungdisa RF, Disama RF, Kaki RF and Inglongkiri RF. The sanctuary is an integral part of Dhansiri-Lumding elephant reserve and the famed Inglongkiri sacred grove. The vegetation is of semievergreen and moist-deciduous types. Important fauna include Pyxidea mouhotii, Manouria emys, Python molurus, Ophiophagus hannah, Hoolock hoolock, Macaca

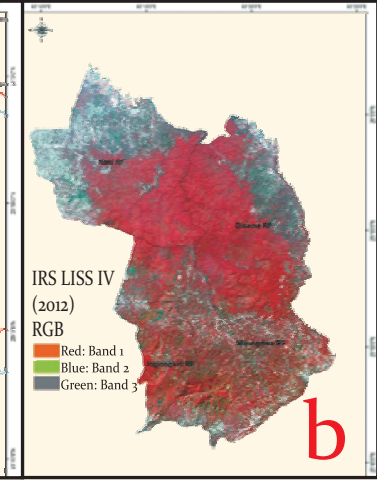

nemestrina, Macaca arctoides and Trachypithecus pileatus. Dimocarpus longam, Gnetum gnemon and Rhaphidophora calophylla (endemic to Northeastern region of India) are significant flora. About 98 villages belonging to seven ethnic groups (Karbi, Dimasa, Hmar, Garo, Chakma, Nepali and Adivasi) are located with 52 villages inside the sanctuary and 46 villages in the fringes of the sanctuary. As per 2011 census, the population figure is 4361 (male: 2283; female: 2078). Population record of ethnic groups in the Sanctuary is not adequate as no such information is available in local forest department. The people practice Jhum farming by clearing forest and other vegetation. Food insecurity being a common problem for scarce agricultural land, they often exploit forest resources to supplement food scarcity, nutritional and other requirements.

Data collection and Analysis: Indian Remote Sensing (IRS) P6 LISS-IV multi-season datasets of 2013 have been used to infer vegetation types and land-use mapping on 1: 50,00o scale in addition to Landsat images. Village land boundaries were studied with the help of maps from local Forest Department. Geo-referenced Survey of India maps and layers were uploaded into a GIS program (ArcGIS 10.1) to create and integrate information with aerial photograph and data collected in the field. Eighty farmers from the four RFs were interviewed (semi-structure) to record land-use pattern and extraction of resources from forests; this is followed by visits to Jhum fields and forest areas for personal observation of the anthropogenic activities. Informants were selected on the criterion that, the farmer been practicing Jhum agriculture for ten or more years. To understand threat perceptions to forest cover and biodiversity, a pair-wise ranking was carried out and the number of possible pairs was calculated using the relation $\mathrm{N}(\mathrm{N}-1) / 2$, where $\mathrm{N}$ is the number of factors (threats). Data were presented in tableand graph.

\section{Results and Discussion:}

Diversity and utilization of forest resources in Marat Longri WLS : Forest dwellers in Marat Longri WLS are farmers and essentially depend on the protected area for subsistence and livelihoods. Major use categories of forest products included food, medicines, construction, fuelwood and fodder. Besides, they use forest land as grazing fields for domestic animals. However, utilization of plant resources is more prominent over animal resources. Following semi-structured interview and forest walks the present study, ninety-three (91) plants 


\section{RESEARCH ARTICLE}

with dietary use were recorded from ethnic groups residing in the sanctuary. Almost all parts are consumedleaves (36), tender shoot (24), fruits (30), tuber (9), bark (6), inflorescence (5), petiole (2), root (4), whole plant (2), seed (2), stem (1) and stolon (1) (Fig. 2). Enumeration of plants used by ethnic groups is presented in Table 3 . Tubers of Dioscorea species are the most extensively collected plant resource during the scarcity of the staple food. In addition to food value, many forest resources have trade value in local markets and generate income for poor families. Many wild plants are used for primary health care and forty-one (41) plants from the sanctuary listed in local pharmacopeia are used for treatment of varied ailments like ear-ache, fever, cough and cold, rheumatism, dysentery, burns, cuts, wounds, skin diseases, eye-complaints, jaundice, poisons and many others (Phangchopi et al., 2015). Herbal prescriptions are diverse and being administered as juice, maceration, decoction, paste, ash, poultice, fumes, oil, gum, resin, etc. Some plants (Spilanthes paniculata, Amomum aromaticum, Blumia lanceolaria) are used in aroma therapy and as baths.

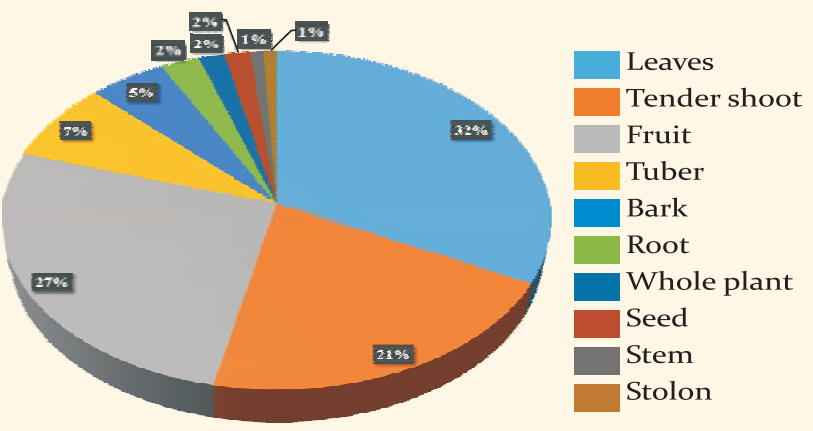

Figure-2: Pie graph showing distribution of plant parts used as food by local inhabitant.

Habitatdegradation: Change in land-use pattern particularly Jhum (shifting cultivation) and agricultural expansion, encroachment, unsustainable collection practices, illegal felling and animal grazing are potent threats to the sanctuary. The Jhum (Fig. 3) practice begins with the clearing of a patch of forest vegetation and subsequent burning of the dried biomass (slash). Farmers operate minimum tilling with crude implements and sow seeds of multiple crops, paddy being the major one. After one or two crops farmers shift to a new forest plot to start another Jhum cycle. The Jhum operations lead to loss of forest cover and fragmentation of habitat. Along with mature trees, many biota like epiphytes, lianas, arboreal animals and microbes are also eliminated. Fragmentation prevents free movement of fauna and depletion of their natural habitat and niche. Due to the removal of vegetation, the soil is exposed and prone to erosion during monsoon. Surface run-off removes the top soil rendering the soil infertile. This compels farmers to shift from one

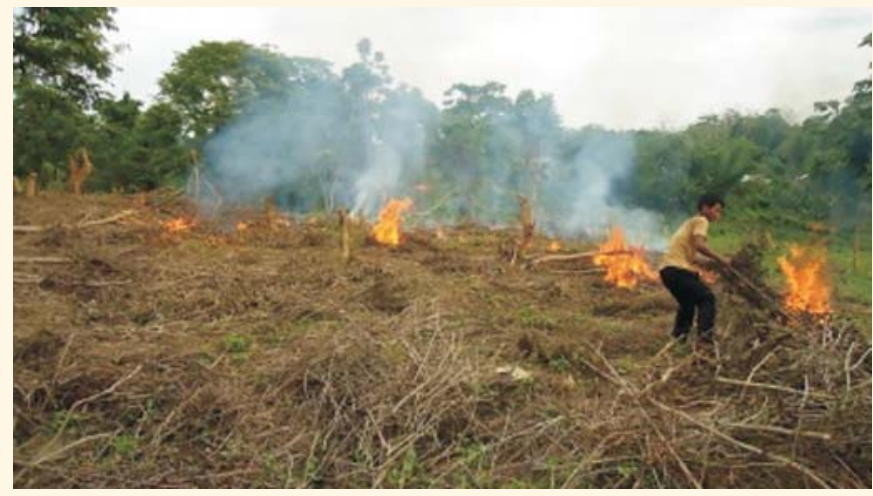

Figure-3: Jhum activities inside Marat Longri WLS

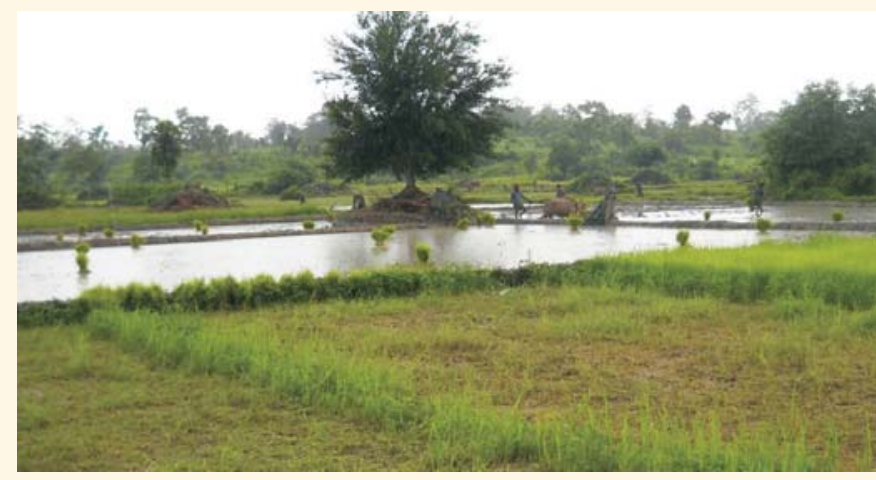

Figure-4: Agricultural expansion in Marat Longri WLS

place to another in search of a new fertile plot of land. The soil becomes barren for many years and provides a perfect platform for invasion by exotic species or weeds. Jhum also contributes to the emission of a large volume of carbon to the atmosphere. Low lying areas, valleys, and marshes are converted to agricultural land (Fig. 4) leading to further loss of potential habitats. Open livestock grazing has hindered regeneration of forest and converted natural forest into grassland (Fig. 5). Unsustainable collection pressure has been the cause of loss of many wild edible resources. The majority of the collectors are female and children; being unable to climb up onto the tree cut the trunk for harvesting the leaves and fruits (example Dillenia indica, Garcinia species, Parkia roxburghii etc.). Such activity leads not only the loss of the tree but also causes loss of habitat for many epiphytic plants and arboreal animals. In the case of Parabaena sagitta, Rapidophora callophyla and Momordica charantia whole plant are uprooted to collect leaves and fruits. Illegal extraction of timber (Fig. 6) is a major intervention in the forest ecosystem. As mature trees are felled, the source of seeds decreases and flora and fauna are displaced. As stated by informants, encroachment, monoculture and agricultural expansion are a major threat to the sanctuary. Forests have been encroached for human settlements (Fig. 7) the trend being most alarming in Kaki and Mijungdisa RFs (Table 1). Jhum operations have resulted in the clearing of more forest areas; agricultural expansion has destroyed low-lying or marshy habitats. 
Table 3: Diversity of wild plant foods used by ethnic groups in Marat Longri WLS.

\begin{tabular}{|c|c|c|}
\hline S.n. Botanical name & Family & Parts used \\
\hline 1. Albizia myriophylla Benth. & Mimosaceae & Bark \\
\hline 2. Aegle marmelos (L.) Corr. & Rutaceae & Fruit \\
\hline 3. Alpinia allughas (Retz.) Rosc. Griseb. & Zingiberaceae & Tender shoot \\
\hline 4. Alternanthera philoxeroides (Mart.) & Amaranthaceae & Tender shoot \\
\hline 5. Alternantherasessilis (L.) R.Br. ex D.C. & Amaranthaceae & Tender shoot \\
\hline 6. Amorphophalus sylvatica(Roxb.) Schott. & Araceae & Tuber \\
\hline 7. Amphineuron opulentum (Kaulf) Holtt. & Thelypteridacea€ & eLeaf \\
\hline 8. Antidesma acidum Retz. & Euphorbiaceae & Leaf \\
\hline 9. Artocarpus lakoocha Roxb. & Moraceae & Bark, leaf \\
\hline 10. Azadirachta indica A. Juss. & Miliaceae & Leaf \\
\hline 11. Baccaurea ramiflora Lour. & Euphorbiaceae & Fruit, leaf \\
\hline 12. Bambusa sp. & Poaceae & Tender shoot, leaf \\
\hline 13. Bauhinia racemosa Lamk. & Caesalpiniaceae & Leaves, tender shoot \\
\hline 14. Bauhinia variegata $\mathrm{L}$. & Caesalpiniaceae & Leaf \\
\hline 15. Blumea sp. & Asteraceae & Leaf \\
\hline 16. Callicarpa arborea Roxb. & Verbenaceae & Bark \\
\hline 17. Calotropis gigantea(L.) R. Br. Ex Ait. & Asclepiadaceae & Leaf \\
\hline 18. Capsicum frutescens L. & Solanaceae & Fruit, leaf \\
\hline 19. Centella asiatica (L.) Urban & Apiaceae & Leaf \\
\hline 20. Cephalandra indicaNaud. & Cucurbitaceae & Fruit \\
\hline 21. Cinnamomum verumPresl. & Lauraceae & Bark \\
\hline 22. Citrus maxima (Burm.) Merr. & Rutaceae & Fruit \\
\hline 23. Citrus sp. & Rutaceae & Fruit \\
\hline 24. Clerodendrum colebrookianumWalp. & Verbinaceae & Tender shoot \\
\hline 25. Coix gigantae J.G. Konig ex Roxb. & Poaceae & Whole plant, fruit \\
\hline 26. Colocasia esculenta (L.) Schott & Araceae & Stolon, petiole, leaf \\
\hline 27. Combretum roxburghii Spreng. & Combritaceae & Bark \\
\hline 28. Commelina benghalensis L. & Commelinaceae & Tender shoot \\
\hline 29. Costus speciosus (Koen.) J.E. Smith & Zingiberaceae & Rhizome, stem, leaf \\
\hline
\end{tabular}

30. Croton joufraRoxb.

31. Deeringia amaranthoides (Lamk.) Merr.

32. Dillenia indica L.

33. Dillenia pentagyna Roxb.

34. Dillenia scabrella Roxb.

35. Dioscorea alata L.

36. Dioscorea esculenta (Lour.) Burk.

37. Dioscorea glabra Roxb.

38. Dioscorea pentaphylla L.

39. Diplazium esculentum (Retz.) Sw.

40. Eilingeralo roglosa (Gagnet.) R.M.Sm.

41. Emblica officinalis Gaertn.

42. Enhydra fluctuans Lour.

43. Ficus hispida L.f.

44. Garcenia lancifolia Roxb.

45. Garcinia pedunculata Roxb.

46. Garcinia tinctoria(DC.) W.F. Wight

47. Gnetum gnemon L.

48. Gymnopetalum cochinchinense (Lour.) Kurtz

\section{Euphorbiaceae Leaf \\ Amaranthaceae Tender shoot \\ Dilleniaceae Fruit \\ Dilleniaceae Fruit \\ Dilleniaceae Fruit \\ Dioscoreaceae Tuber, leaf \\ Dioscoreaceae Tuber, leaf \\ Dioscoreaceae Tuber, leaf \\ Dioscoreaceae Tuber, leaf \\ Athyriaceae Leaf \\ Zingiberaceae Root \\ Euphorbiaceae Fruit}

Asteraceae Tender shoot

$\begin{array}{ll}\text { Moraceae } & \text { Leaf } \\ \text { Clusiaceae } & \text { Fruit } \\ \text { Clusiaceae } & \text { Fruit } \\ \text { Clusiaceae } & \text { Fruit } \\ \text { Gnetaceae } & \text { Fruit, leaf } \\ \text { Cucurbitaceae } & \text { Fruit, leaf }\end{array}$

Uses

Fermentation starter cake

Eaten raw, purgative, cattle feed

Vegetable

Vegetable, paste for cattle wounds.

Vegetable, juice given in jaundice and liver problem

Cooked with dry fish or alkali, pig feed

Vegetable, insecticides.

Vegetable

Masticatory, fodder

Chutney, medicine for skin disease and pimples

Leaf as vegetable, fruit eaten raw,fodder

Vegetable, fodder

Chutney,fodder

Chutney, fodder

Vegetable, medicine for rheumatic fever, also used as painkiller

Masticatory

Cooked along with alkali

Vegetable, spice, medicine for caught.

Vegetable, raw leaf is consumed to relief stomach disorder.

Vegetable, also eaten raw, cattle feed

Spice

Eaten raw

Eaten raw

Vegetable, medicine for hypertension

Famine food, fodder

Vegetable, pig feed

Masticatory

Vegetable, cattle feed

Vegetable, boiled root juice for urinary stone cases, hot fomentation of stem

juice is used as ear-drop against ear-ache

Fermentation starter cake

Vegetable

Vegetable, medicine for dysentery

Eaten raw

Eaten raw

Famine food, fodder

Famine food, fodder

Famine food, fodder

Famine food, fodder

Vegetable

Masticatory

Eaten raw, medicine for hair fall, stomach trouble

Vegetable, used in stomach trouble, paste of leaf for skin disease, consumption of row leaf is good for eye site, fodder

Vegetable

Eaten raw

Eaten raw

Eaten raw

Vegetable, fruit eaten after roasting

Chutney 
S.n. Botanical name

49. Hodgsonia macrocarpa (B1.) Cogn. [

50. Homalomena aromatica Schott

51. Houttuynia cordataThunb.

52. Ipomoea aquatica Forsk.

53. Laportea interrupta (L.) Chew.

54. Lasia spinosa (L.) Thw.

55. Mangifera sylvatica Roxb.

56. Maranta arundinacea L.

57. Momordica charantia L.

58. Momordica cochinchinensis (Lour.) Spreng 59. Monochoria hastata (L.) Solms

6o. Murraya koenigii (L.) Spreng

61. Musa sapientum L.

62. Nephelium longana Camb.

63. Nymphaea lotus L.

64. Oenanthe javanica (Blume) DC.

65. Olaxa cuminata Wall. Ex Benth.

66. Oroxy lumindicum (L.) Vent.

67. Oxalis corniculata L.

68. Paederia scandens (Lour.) Merr.

69. Parabaena sagittataMiers.

70. Parkia timoriana (DC.) Merr.

71. Phlogacanthus thyrsiformis (Hard.) M.N.

72. Physalis peruviana L.

73. Piper thomsonii Hook. $\mathrm{f}$.

74. Pogostemon pubescentsBenth.

75. Reidia hamiltoniana (Mueller) Cowan.

76. Rhynchotechumellipticum (Dietr.) A. DC.

77. Sapindus mukorossi Gaertn.

78. Sauropus androgynus Merr.

79. Smilax glabraRoxb.

8o. Solanum nigrum L.

81. Solanum torvum Sw.

82. Spilanthes calva DC.

83. Spondias pinnata(L. f.) Kurz

84. Tabernaemontana divaricata (L.)

Br. Ex Roem. \&Schult.s

85. Tamarindas indica L.

86. Terminalia chebula Retz.

87. Vernonia cineria (L.) Less.

88. Xanthium strumarium L.

89. Zanthoxylum oxyphyllum Edgew.

90. Zingiber zerumbet(L.) Rose ex Sm.

91. Zizyphus mauritiana Lamk.

\author{
Family
}

Parts used

Cucurbitaceae Seed

Araceae Leaf, tuber

Saururaceae Leaf

Convolvulaceae Tender shoot, leaf

Urticaceae Leaf, root

Araceae Leaf

Anacardiaceae Fruit

Marantaceae Tuber

Cucurbitaceae Leaf, fruit

Cucurbitaceae Fruit, tender shoot

Pontederiaceae Tender shoot, leaf

Rutaceae Leaf

Musaceae Tender petiole, spathe, fruit

Sapindaceae Fruit

Nymphaeaceae Root, seed

Apiaceae Tender shoot

Olacaceae Tender shoot

Oxalidaceae Whole plant

Rubiaceae Tender shoot, leaf

Menispermaceae Leaf, tender shoot

Mimosaceae

Fruit

Uses

Chutney

Vegetable, pig feed

Vegetable

Vegetable, leaf juice is given for blood purification, fodder

Leaf as vegetable, roots as anthelmintic, vegetable, fodder

Vegetable

Eaten raw; fodder

Famine food, to increase lactation.

Vegetable, juice for dysentery; leaf in

fermentation starter cakes.

Vegetable

Vegetable, leaf juice for curing boils,

fodder

Vegetable, curry flavour, medicine for constipation

Vegetable, beer is prepared from ripe

fruit, urgative, pig feed

Eaten raw

Seeds are edible, root juice given in piles

Vegetable

Vegetable

Acanthaceae Tender shoots, inflorescenceChutney, medicine for dysentery

Solanaceae Fruits, tender shoot Vegetable

Piperaceae Leaf

Lamiaceae Tender shoots

Euphorbiaceae Tender shoot, fruit.

Gesneriaceae Leaf

Sapindaceae Fruit

Euphorbiaceae Leaf

Smilacaceae Tuber

Solanaceae Tender shoot

Solanaceae Fruit

Asteraceae Inflorescence, tender shoot

Anacardiaceae Fruit

Apocynaceae Fruit

Caesalpiniaceae Fruit, leaf

Datiscaceae Fruit

Asteraceae Tender shoot

Asteraceae Leaf

Asteraceae Tender shoot

Zingiberaceae Inflorescence

Rhamnaceae Fruit
Eaten with betel nut

Vegetable

Vegetable

Vegetable

Eaten raw

Vegetable

Famine food

Vegetable

Vegetable

Vegetable, edicine for tooth ache and cough

Eaten raw

Eaten after roasting

Leaves as vegetable, fruit eaten raw, fodder

Eaten raw, edicine for caught, dysentery, pest is apply on scalp to reduce hair fall.

Vegetable

Vegetable

Vegetable

Vegetable

Eaten raw, curry, making pickle 
Human oriented various activities inside Marat Longri Wild Life Sancturay

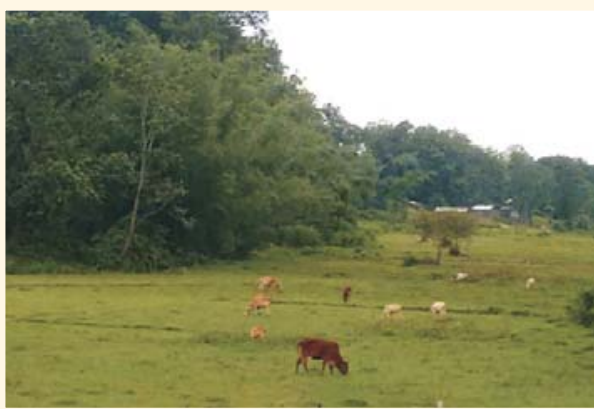

Figure-5: Animal grazing land

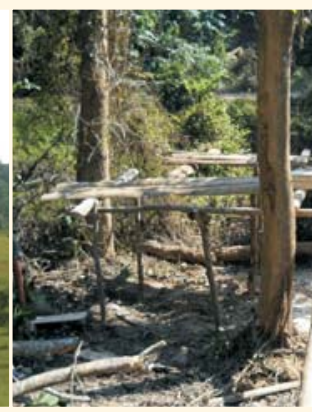

Figure-6: Illegal extraction

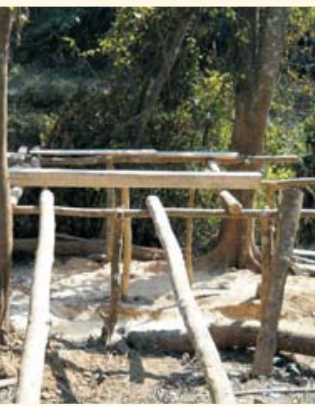

ion of timber

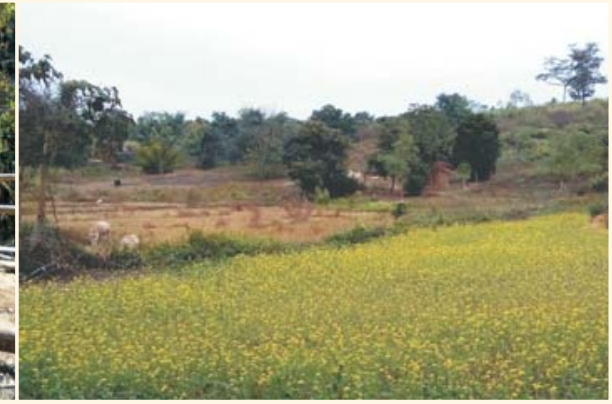

Figure 7: Human encroachment
Table-1: Encroachment position in Marat Longri WLS as on 1st January 2014

\begin{tabular}{|c|c|c|c|c|c|}
\hline $\begin{array}{l}\mathrm{S} . \\
\mathrm{N}\end{array}$ & $\begin{array}{l}\text { Name of Reser } \\
\text { Forest (RF) }\end{array}$ & $\begin{array}{l}\text { Total a } \\
(\mathrm{km} 2)\end{array}$ & $\begin{array}{l}\text { Encroach- } \\
\text { ment (\%) }\end{array}$ & $\begin{array}{l}\text { No. of } \\
\text { houses }\end{array}$ & $\begin{array}{l}\text { No. of } \\
\text { Encroacher }\end{array}$ \\
\hline 1 & Kaki RF & 118.38 & $24.29 \%$ & 314 & 1750 \\
\hline 2 & Disama RF & 116.42 & $25.65 \%$ & 170 & 994 \\
\hline 3 & Mijungdisa RF & 109.18 & $70.96 \%$ & 246 & 1381 \\
\hline 4 & Inglongkiri RF & $44 \cdot 77$ & $40.82 \%$ & 37 & 236 \\
\hline
\end{tabular}

(Source: GIS and Remote Sensing Lab. PCCF Office, Diphu. Directorate of Statistical Off ice, Diphu).

Table 2: Fragmentation status (percent) of the four Reserve Forests in Marat Longri WLS

\begin{tabular}{lllll}
\hline - Forest class & Kaki & Disama & Mijungdisa & Inglongkiri \\
\hline - Very dense forest & 0.32 & 11.50 & 1.86 & 12.07 \\
- Moderately dense & 8.44 & 24.12 & 13.75 & 13.58 \\
forest & & & & \\
- Open forest & 34.86 & 40.10 & 1.16 & 38.36 \\
- Non-forest & 42.97 & 23.69 & 46.59 & 35.98 \\
\hline
\end{tabular}

(Source: GIS and Remote Sensing Lab. PCCF Off ice, Diphu)

Pair-wise ranking of five factors (Jhum, collection pressure, illegal felling, agriculture expansion, and encroachment) (Table 3) highlighted people perception on forest degradation in the Marat Longri [M1] WLS. The total sum of each factor (calculated using the relation $\mathrm{N}$ $(\mathrm{N}-1) / 2)$ varied among informants of different RF. The result of pair-wise ranking revealed Jhum (3160) is the major threat to forest cover followed by illegal felling (2850), agricultural expansion (2346), encroachment (2211) and collection pressure (2080). This trend is mainly due to increase demand for arable land by the burgeoning human population. In summary, all the above factors contribute towards the decline of forest cover directly or indirectly and loss of biodiversity there-in.

Indian Remote Sensing (IRS) P6 LISS-IV multi-season datasets of 2014, revealed that the Marat Longri WLS has an existing forest cover of only 40.43 percent. The sanctuary is under pressure from encroachment; about $40.43 \%$ (approx.) of the sanctuary area has been cleared for settlement and agricultural activities (Table 1). Out of the four Reserve Forest constituting the sanctuary,
Mijungdisa RF topped the list with the highest loss of forest cover (i.e. 70.96\%) which is followed by Inglongkiri RF (40.82\%), Disama RF (25.65\%) and Kaki RF (24.29\%). Fragmentation status of the four RFs is shown in Fig. 6. The main reason for the loss of forest cover is due to shifting cultivation (Jhum) as vast tracts of hilly slopes have been badly denuded and extension of encroachment in somearea.

\section{Conclusion:}

It has been observed that biological and economic importance of Marat Longri WLS has been partially realized or assessed. Forest dwellers have certain rights to forest resources however, there is lack of balance in utilization and conservation of forest biodiversity; large scale clearing of forest vegetation is reminiscent of this. In spite of legal status, illegal activities are abundant and widespread in the sanctuary. The present report provides a quantitative assessment of the disturbances threatening RFs of the sanctuary. This information can be useful to develop and propose opportunities for improving protection of the protected area. Unless proper strategies are put in place, threats to the forests and its biodiversity will remain and the very objectives of establishing the sanctuary will fail miserably. With the loss of these forests, Marat Longri WLS will lose an invaluable natural heritage and a major economic resource. The consequences of this loss would likely be devastating for the people, the economy, and the biodiversity of Karbi Anglong district. More engagement with forest dwellers is needed to create strong mass awareness about forest conservation and its benefits. There is a need to look for present land-use pattern with alternative agroforestry system that will carter the needs of local inhabitants and lessen pressure on forest resources. Domestication of forest plants in homestead gardens in one way can help in food production and economy; this will minimize dependence on forest products and reduce conflicts with wildlife.

Acknowledgements:

Authors are grateful to the Department of Environment and Forest, Karbi Anglong Autonomous Council for granting 


\section{RESEARCH ARTICLE}

permission to undertake the present study in the Sanctuary. We are thankful to local guides for assistance and hospitality during the field work. We also thank the GIS team of forest department for assistance. Authors also thank to Institutional Biotech Hub, funded by Department of Biotechnology, Govt. of India for infrastructural support.

\section{References:}

Ambastha, K.R. \& Jha C.S. (2010): Geospatial Analysis of Tamil Nadu Eastern Ghats Forest Types at Landscape level with reference to Fragmentation and Species Diversity. J. Ind. Soc. Rem. Sensing. 38:453-463.

Boucher, D.H., Elias, P., Lininger, K., May-Tobin C., Roquemore, S. \& Saxon E. (2011): The Root of the Problem: What's Driving Tropical Deforestation Today? (Cambridge, MA: Union of Concerned Scientists) Pub. by: David Lubin Memorial Library, Food and Agriculture Organization of the U. N.

CBD- Secretariat of the Convention on Biological Diversity (2004): Biodiversity issues for consideration in the planning, establishment and management of protected area sites and networks. Montreal, SCBD, 164 pages. (CBD Technical Series no. 15).

De Fries, R., Rudel, T.K., Uriarte, M. \& Hansen, M. (2010): Deforestation driven by urban population growth and agricultural trade in the twenty-first century. Nat. Geosci., 3:178-181.

Geist, H. \& Lambin, E. (2001): What drives tropical deforestation? A meta-analysis of proximate and underlying causes of deforestation based on sub-national case study evidence, Land-Use and Land-Cover Change (LUCC), Project, International Geosphere-Biosphere Programme (IGBP), LUCC Report Series: 4.
Kar, A. \& Borthakur, S.K. (2007): Wild vegetables sold in local markets of Karbi Anglong, Assam: Ind. J. Trad. Know. 6(1): 169-172.

Krishna, P.H. \& Reddy C. S. (2012): Assessment of Increasing Threat of Forest Fires in Rajasthan, India using multitemporal remote sensing data (2005-2010). Curr. Sci., 102(9): 1288-1297.

Latawiec, A. \& Agol, D. (2015): Sustainability Indicators in Practice (e-book; open access). Pub. by: DE GRUYTER OPEN, p. 271.

Pattanaik, C., Reddy, C.S. \& Murthy, M.S.R. (2010): Geospatial Modelling of Biological Richness in Kuldiha Wildlife Sanctuary of Orissa, India. L. Ind. Soc. Rem. Sens., 38:477485 .

Phangchopi, U., Tamuli, A.K. \& Teron, R. (2014): Inventory of wild food plants in Marat Longri Wildlife Sanctuary in Assam, India. Pleione. 8(2):331-343.

Phangchopi, U., Tamuli, A.K. \& Teron, R. (2015): Diversity of wild edible plants in Marat Longri Wildlife Sanctuary, Assam: Ind. J. Nat. Prod. Res., 6(4):305-313.

Roy, P.S., Kushwaha, S.P.S., Roy, A., Karnataka, H. \& Saran, S. (2013): Biodiversity Characterization at Landscape level using Geospatial Model. Anais XVI Simpósio Brasileiro de Sensoriamento Remoto - SBSR, Foz do Iguaçu, PR, Brasil, INPE. 3321- 3328.

Salem, B.B. (2003): Application of GIS to biodiversity monitoring. L.Arid Environ., 54: 91-114.

Talukdar, B.K. (2014): Status, Trends and Challenges of forest conservation in Assam, India. XII World Forestry Congress, $1-6$. 